\title{
HUBUNGAN WORK FAMILY CONFLICT DENGAN STRES KERJA PADA PERAWAT WANITA DI RUMAH SAKIT PUTRI HIJAU MEDAN
}

\author{
Relationship Work Family Conflict With Work Stress Nurse Women's \\ In Putri Hijau Hospital Medan
}

\author{
Mompang Tua Parlagutan ${ }^{1}$ dan Muchti Yuda Pratama \\ ${ }^{1,2}$ Dosen Tetap Yayasan Akper Kesdam I/BB Medan \\ Email : akperkesdam1bbmedan@yahoo.com
}

\begin{abstract}
Abstrak
Penelitian ini merupakan penelitian korelasional yang bertujuan mengetahui hubungan work family conflict dengan stres kerja pada wanita bekerja. Berdasarkan fenomena yang ada, bahwa jumlah wanita berperan ganda yang meningkat dari tahun ke tahun dan tidak jarang peran ganda itu sendiri banyak menimbulkan permasalahan bagi wanita yang menjalaninya.

Konflik peran ganda adalah salah satu bentuk konflik antar peran yang diakibatkan peran dalam pekerjaan dan keluarga saling tidak cocok satu sama lain. Subjek penelitian ini berjumlah 76 orang wanita yang sudah menikah, memiliki anak, dan memiliki anak usia pra sekolah. Tehnik pengambilan sampel dengan menggunakan incidental sampling. Uji linearitas menggunakan compare means test for linearity untuk melihat hubungan antara konflik peran ganda (independent variable) dengan stres kerja (dependent variable) pada wanita bekerja. Alat ukur yang digunakan adalah skala konflik peran ganda yang disusun sendiri oleh peneliti dengan dimensi-dimensi konflik peran ganda yang dikemukakan oleh Greenhause dan Beutell (1985). Skala tingkat stres kerja yang disusun oleh peneliti dengan gejala-gejala stres kerja yang dikemukakan oleh Rice (1992). Skala Konflik peran ganda memiliki nilai reliabilitas $\left(\mathrm{r}_{\mathrm{xx}}\right)=0.890$ dan terdiri dari 54 aitem, sedangkan skala stres kerja memiliki nilai reliabilitas $\left(\mathrm{r}_{\mathrm{xx}}\right)=0.761$ dan terdiri dari 50 aitem.

Analisa penelitian menggunakan Analisa Regresi Linear Sederhana. Berdasarkan Hasil analisa data ditemukan bahwa terdapat hubungan positif antara konflik peran ganda dengan stres kerja dengan nilai $r=0.777, \rho=0.000$. Artinya semakin tinggi konflik peran ganda maka akan semakin tinggi pula tingkat stres kerja yang dimiliki, dan sebaliknya, semakin rendah work family conflict maka tingkat stres kerja akan semakin rendah pula.
\end{abstract}

Kata Kunci: konflik peran ganda, stres kerja, wanita bekerja

\begin{abstract}
This research is a correlational research that aim to know the correlation between work family conflict with work stress on working women. With in the phenomenon, that the amount of work family conflict women who had carrier and family increase from year to year, caused many problems for the women who experienced it.

Work family conflict is one form of conflict that arise between the role of roles in work family conflict with one another. The subject of this research amounted to 76 women who are married, have children, and has a pre-school age children. Sampling techniques using incidental sampling. The linearity use compare means test for linearity to see the correlation between work family conflict (independent variable) with work stress (dependent variable) on working women. Used measure is the dual role by researchers with the dimensions of the conflict in the dual function expressed by Greenhause and Beutell (1985) conflict scale. Work stress level scale, prepared by researchers with the symptoms of work stress is presented by Rice (1992). The work family conflict scale has a value of reliability $\left(\mathrm{r}_{\mathrm{xx}}\right)=0.890$ and consist of 54 items, whereas the Work Stress scale has a value of reliability $\left(\mathrm{r}_{\mathrm{xx}}\right)=0.761$ and consist of 50 items

The analysed of research data using Simple Analyse Reggession Linear. The results showed that there was a positive correlational between work family conflict and work stress with correlation coefficient $r=0.777, \rho=0.000$. The meaning is the more and more high work family conflict then work stress will more and more high, and on the contrary, the more and more low work family conflict then work stress will more and more low.
\end{abstract}

Key words: work family conflict, work stress, working women 


\section{Pendahuluan}

Bekerja bagi manusia sudah menjadi suatu kebutuhan, baik bagi pria maupun bagi wanita. Bekerja mengandung arti melaksanakan suatu tugas yang diakhiri dengan buah karya yang dapat dinikmati oleh manusia yang bersangkutan (As'ad, 1990). Menurut Davis (1991) faktor yang mendorong manusia bekerja adalah adanya kebutuhan yang harus dipenuhi. Aktivitas dalam kerja mengandung unsur kegiatan sosial, menghasilkan sesuatu, dan pada akhirnya bertujuan untuk kebutuhan hidup manusia.

Keterlibatan wanita yang sudah tampak membawa dampak terhadap peran wanita dalam kehidupan keluarga. Fenomena yang terjadi dalam masyarakat adalah semakin banyaknya wanita membantu suami mencari tambahan penghasilan, selain karena didorong oleh kebutuhan ekonomi keluarga, juga wanita semakin dapat mengekspresikan dirinya di tengah-tengah keluarga dan masyarakat. Keadaan ekonomi keluarga mempengaruhi kecenderungan wanita untuk berpartisipasi di luar rumah, agar dapat membantu meningkatkan perekonomian keluarga (Wolfman, 1994).

Motivasi untuk bekerja dengan mendapat penghasilan khususnya untuk wanita golongan menengah tidak lagi hanya untuk ikut memenuhi kebutuhan ekonomi keluarga, melainkan juga untuk menggunakan keterampilan dan pengetahuan yang telah mereka peroleh serta untuk mengembangkan dan mengaktulisasikan diri (Ihromi, 2013).

Di kehidupan keluarga, suami dan istri umumnya memegang peranan dalam pembinaan kesejahteraan bersama, secara fisik, materi maupun spiritual, juga dalam meningkatkan kedudukan keluarga dalam masyarakat untuk memperoleh penghasilan yang pada dasarnya dimaksudkan untuk memenuhi kebutuhan ekonomi keluarga.

Tugas untuk memperoleh penghasilan keluarga secara tradisional terutama dibebankan kepada suami sebagai kepala keluarga, sedangkan peran istri dalam hal ini dianggap sebagai penambah penghasilan keluarga. Dalam golongan berpernghasilan rendah, istri lebih berperan serta dalam memperoleh penghasilan untuk keluarga.

Hasil survey AC. Nelson (dalam Ubaydillah, 2013) menunjukkan adanya kebangkitan kaum wanita di Asia Tenggara dalam hal jabatan bisnis, politik, budaya, dan lain-lain. Hal tersebut dapat dilihat dalam kehidupan kita sehari-hari pun kita juga bisa membuktikan bahwa jumlah kaum wanita yang keluar dari rumah untuk mengisi jabatan di organisasi tertentu semakin hari semakin meningkat. Bahkan Indonesia dan Philifina mengangkat wanita menduduki jabatan eksekutif tertinggi.

Banyak persoalan yang dialami oleh para wanita ibu rumah tangga yang bekerja di luar rumah, seperti bagaimana mengatur waktu dengan suami dan anak hingga mengurus tugas-tugas rumah tangga dengan baik. Ada yang bisa menikmati peran gandanya, namun ada yang merasa kesulitan hingga akhirnya persoalanpersoalan rumit semakin berkem-bang dalam hidup sehari-hari (Yulia, 2012).

Pada umumnya, wanita banyak menghadapi masalah psikologis karena adanya berbagai perubahan yang dialami saat menikah, antara lain perubahan peran sebagai istri dan ibu rumah tangga, bahkan juga sebagai ibu bekerja. (Pujiastuti dan Retnowati, 2012).

Wanita yang menjadi istri dan yang bekerja sering hidup dalam pertentangan yang tajam antara perannya di dalam dan di luar rumah. Banyak wanita yang bekerja full-time melaporkan bahwa mereka merasa bersalah karena sepanjang hari meninggalkan rumah. Namun, setibanya di rumah mereka merasa tertekan karena tuntutan anak-anak dan suami. Sering sekali timbul perselisihan antara suami-istri yang terus-menerus tentang pekerjaan atau gaji siapa yang lebih penting bagi kelangsungan hidup maupun hal lainnya misalnya masalah tanggung jawab dalam mendidik dan merawat anak-anak (Ubaydillah, 2003).

Berdasarkan Penelitian Moen dan McClain (1990) terbukti bahwa dimana wanita yang bekerja full-time lebih ingin mempersingkat jam kerjanya untuk mengurangi ketegangan akibat peran pekerjaan dan keluarga dibandingkan dengan wanita yang bekerja part-time.

Dalam penelitian yang dilakukan Oleh Valdez dan Gutek (1988) menemukan bahwa wanita dengan jabatan profesional atau manajerial ternyata memiliki anak yang relatif lebih sedikit dibandingkan dengan wanita dengan tingkat jabatan yang lebih rendah. Hal ini karena konflik peran meningkat seiring dengan jumlah anak. Oleh karena itu dalam mengantisipasi kemungkinan terjadinya konflik peran ganda yang tinggi, wanita cenderung memilih untuk membatasi jumlah anak. Hal ini bisa disebabkan karena wanita pada golongan tersebut lebih tinggi keterlibatannya dalam pekerjaan sehingga untuk meningkatkan kualitas hubungan dengan anak, mereka memilih untuk memiliki anak dengan jumlah yang sedikit. Selain itu sekarang ditemukan adanya hubungan yang positif antara jumlah anak dengan kesehatan mental wanita yang bekerja. Holohan dan Gilbert (dalam Valdez \& Gutek, 1988) menemukan adanya stres kerja pada orang tua yang memiliki anak-anak usia pra sekolah karena adanya keterlibatan wanita yang bekerja dengan anak yang masih kecil lebih tinggi saat anak-anak masih kecil.

Meningkatnya peran wanita sebagai pencari nafkah keluarga dan kenyataan bahwa mereka juga berperan untuk meningkatkan kedudukan keluarga, maka bertambahlah pula 
masalah-masalah yang timbul. Kedua peran tersebut sama-sama membutuhkan waktu, tenaga dan perhatian, sehingga jika peran yang satu dilakukan dengan baik, yang lain terabaikan sehingga timbullah konflik peran. Masalah ini timbul apabila yang bekerja adalah ibu rumah tangga yang mempunyai anak-anak dan masih membutuhkan pengasuhan fisik maupun rohaniah (Ihromi, 2013).

Masalah lain yang timbul adalah akibat perubahan pola hubungan suami istri. Seorang istri yang menjadi ibu rumah tangga dan menjadi pencari nafkah (berperan ganda) harus memenuhi tugas sebagai ibu rumah tangga dan diharapkan dapat menjalankan perannya sebagai seorang istri dan sekaligus pencari nafkah. Dalam hal ini dapat dibayangkan konflik peran dapat terjadi.

Menurut Munandar (2001) konflik peran muncul jika seorang pekerja mengalami pertentangan antara tangggung jawab yang dia miliki dengan tugas-tugas yang harus dilakukannya.

House dan Rizzo (dalam Steven, 2000) mengatakan bahwa konflik peran secara umum didefinisikan kemunculan yang simultan dari dua atau lebih tekanan peran. Kehadiran salah satu peran akan menyebabkan kesulitan dalam memenuhi tuntutan peran yang lain. Kahn (Hardyastuti, 2001) mengatakan bahwa harapan orang lain terhadap berbagai peran yang harus dilakukan seseorang dapat menimbulkan konflik. Konflik terjadi apabila harapan peran mengakibatkan seseorang sulit membagi waktu dan sulit untuk melaksanakan salah satu peran karena hadirnya peran yang lain.

Hardyastuti (2001) mengatakan bahwa konflik peran lebih dirasakan oleh wanita dari pada laki-laki. Menurut Moen (dalam Hardyastuti, 2001) perbedaan terjadi dikarenakan sifat permintaan peran yang berbeda. Wanita lebih dihadapkan pada permintaan antara peran kerja dan peran keluarga secara serentak yang memerlukan prioritas dalam menjalankan kedua peran tersebut. Hal tersebut dapat menimbulkan konflik apabila wanita tidak dapat membagi waktu antara perannya sebagai ibu rumah tangga dan sebagai pekerja.

Ihromi (1990) juga menyatakan bahwa konflik peran akan lebih dirasakan oleh wanita yang bekerja. Hal ini disebabkan karena wanita yang bekerja akan menghadapi konflik peran sebagai wanita karier sekaligus ibu rumah tangga. Terutama dengan alam kebudayaan Indonesia, wanita akan dituntut perannya sebagai ibu rumah tangga yang baik, sehingga banyak wanita karir yang serba salah ketika harus bekerja.

Berdasarkan pemaparan tersebut, maka dapat disimpulkan bahwa wanita sebagai ibu rumah tangga dan sebagai ibu bekerja (berperan ganda) yang mana peran tersebut sama-sama membutuhkan waktu, tenaga dan perhatian, sehingga apabila peran yang satu dilakukan dengan baik, yang lain terabaikan sehingga timbullah konflik. Apabila terjadi ketidaksesuaian antara situasi keluarga dan situasi pekerjaan, maka hal inilah yang menyebabkan terjadinya konflik peran. Peran ganda yang dijalankan wanita, baik sebagai ibu rumah tangga maupun sebagai wanita yang bekerja, dapat menimbulkan konflik yang berkepanjangan dan dapat menyebabkan timbulnya respon fisik, psikologis dan tingkah laku sebagai bentuk adaptasi terhadap kondisi mengancam yang disebut dengan stres. Peneliti menyimpulkan bahwa terdapat kaitan antara konflik peran ganda dengan stres kerja. Maka peneliti ingin melihat hubungan antara konflik peran ganda dengan stres kerja pada wanita bekerja.

\section{Tinjauan Pustaka \\ Pengertian stres kerja}

Dalam hubungannya dengan pekerjaan, setiap orang pernah mengalami stres. Adakalanya stres yang dialami seseorang itu adalah kecil dan hampir tak berarti, namun bagi yang lainnya dianggap sangat mengganggu dan berlanjut dalam waktu yang relatif lama (Efendi, 2001). Pekerjaan dapat menimbulkan stres karena pekerjaan memainkan peran yang sangat penting dalam kehidupan manusia (Dawis dan Martha, 1990). Lingkungan kerja, sebagaimana lingkunganlingkungan lainnya, menuntut adanya penyesuaian diri dari individu yang menempatinya. Oleh karena itu, individu akan memiliki kemungkinan untuk mengalami suatu keadaan stres dalam lingkungan kerja (Rice, 1992).

Secara sederhana stres dapat didefinisikan sebagai suatu keadaan dimana individu terganggu keseimbangannya (Dharmawan, 2005). Sering pula stres diartikan sebagai perasaan khawatir dan takut (Dawis dan Martha, 1990). Hans Selye (dalam Efendi, 2001) yang dikenal sebagai father of stress theory mendefinisikan stres sebagai respon tubuh non-spesifik terhadap segala tekanan yang menimpanya.

Stres atau ketegangan timbul sebagai suatu hasil ketidakseimbangan antara persepsi orang tersebut mengenai tuntutan yang dihadapinya dan persepsinya mengenai kemampuannya untuk menanggulangi tuntutan tersebut (Rice, 1992). Stres dapat disebabkan oleh apapun yang menstimulasi kita, hal itu adalah bagian dari kehidupan. Beberapa tingkatan stres dapat distimulasi, namun bila terlalu banyak akan bisa merusak (Lazarus, dalam Austin, 2004). Stres berhubungan dengan dengan situasi lingkungan yang dipersepsikan sebagai suatu tekanan yang melampaui kemampuan dan keadaan diri seseorang untuk mengatasinya (McGrath, dalam Chandraiah, 2003). Penghayatan stres ditentukan oleh penafsiran tentang tuntutan apa yang dihadapi dan oleh analisis dari sumber-sumber yang dimiliki 
untuk mampu menghadapi tuntutan (Munandar, 2001).

Stres yang kemunculannya mengacu pada pekerjaan seseorang disebut stres kerja (Austin, 2004). Stres kerja menurut Kahn, dkk (dalam Cooper, 2003) merupakan suatu proses yang kompleks, bervariasi, dan dinamis dimana stressor, pandangan tentang stres itu sendiri, respon singkat, dampak kesehatan, dan variabel-variabelnya saling berkaitan. Cooper (1998) mengemukakan bahwa stres kerja adalah ketidakmampuan untuk memahami atau menghadapi tekanan, di mana tingkat stres tiap individu dapat berbeda-beda dan bereaksi sesuai perubahan lingkungan atau keadaan.

Menurut Handoko (1995) Stres kerja merupakan suatu kondisi ketegangan yang mempengaruhi emosi, proses berpikir dan kondisi seseorang. Stres yang terlalu besar dapat mengancam kemampuan seseorang untuk menghadapi lingkungan. Selye (dalam Beehr, 1995) menyatakan bahwa stres kerja dapat diartikan sebagai sumber atau stressor kerja yang menyebabkan reaksi individu berupa reaksi fisiologis, psikologis, dan perilaku.

\section{Konflik peran ganda}

Konflik peran menurut Beehr (1995) adalah adanya ketidakcocokan antara harapanharapan yang berkaitan dengan suatu peran dimana dalam kondisi yang cukup ekstrim, kehadiran dua atau lebih harapan peran atau tekanan akan sangat bertolak belakang sehingga peran yang lain tidak dapat dijalankan.

Paden dan Buchler (dalam Simon, 2002) mendefinisikan konflik peran ganda merupakan konflik peran yang muncul antara harapan dari dua peran yang berbeda yang dimiliki oleh seseorang. Di pekerjaan, seorang wanita yang profesional diharapkan untuk agresif, kompetitif, dan dapat menjalankan komitmennya pada pekerjaan. Di rumah, wanita sering kali diharapkan untuk merawat anak, menyayangi dan menjaga suaminya.

Netemeyer (dalam Hennessy, 2005) mendefinisikan konflik peran ganda sebagai konflik yang muncul akibat tanggung jawab yang berhubungan dengan pekerjaan mengganggu permintaan, waktu dan ketegangan dalam keluarga. Hennessy (2005) selanjutnya mendefisikan konflik peran ganda ketika konflik yang terjadi sebagai hasil dari kewajiban pekerjaan yang mengganggu kehidupan rumah tangga.

Jadi dari beberapa pengertian di atas konflik peran ganda adalah salah satu bentuk konflik antar peran yang diakibatkan pekerjaan dan keluarga saling tidak cocok satu sama lain, kewajiban pekerjaan yang mengganggu kehidupan rumah tangga, permintaan, waktu dan ketegangan dalam keluarga yang disebabkan harapan dari dua peran yang berbeda.

\section{Dimensi-dimensi konflik peran ganda}

Menurut Greenhause dan Beutell (1985)

konflik peran ganda itu bersifat bi-directional dan multidimensi. Bi-directional terdiri dari:

a. work-family conflict yaitu konflik yang muncul dikarenakan tanggung jawab pekerjaan yang mengganggu tanggung jawab terhadap keluarga.

b. family-work conflict yaitu konflik yang muncul dikarenakan tanggung jawab terhadap keluarga mengganggu tanggung jawab terhadap pekerjaan.

Menurut Greenhause dan Beutell (1985) multidimensi dari konflik peran ganda muncul dari masing-masing direction dimana antara keduanya baik itu work-family conflict maupun family-work conflict masing-masing memiliki 3 dimensi yaitu: time-based conflict, strain-based conflict, behaviorbased conflict. Greenhaus dan Beutell (dalam Hennessy, 2005) mendefinisikan tiga dimensi dari konflik peran ganda, yaitu:

a. time-based conflict, yaitu konflik yang terjadi karena waktu yang digunakan untuk memenuhi satu peran tidak dapat digunakan untuk memenuhi peran lainnya artinya pada saat yang bersamaan seorang yang mengalami konflik peran ganda tidak akan bisa melakukan dua atau lebih peran sekaligus.

b. strain-based conflict, yaitu ketegangan yang dihasilkan oleh salah satu peran membuat seseorang sulit untuk memenuhi tuntutan perannya yang lain. Sebagai contoh, seorang ibu yang seharian bekerja, ia akan merasa lelah, dan hal itu membuatnya sulit untuk duduk dengan nyaman menemani anak menyelesaikan pekerjaan rumahnya. Ketegangan peran ini bisa termasuk stres, tekanan darah meningkat, kecemasan, cepat marah dan sakit kepala.

c. behavior-based conflict, yaitu konflik yang muncul ketika pengharapan dari suatu perilaku yang berbeda dengan pengharapan dari perilaku peran lainnya. Sebagai contoh, seorang wanita yang merupakan manajer eksekutif dari suatu perusahaan mungkin diharapkan untuk agresif dan objektif terhadap pekerjaan, tetapi keluarganya mempunyai pengharapan lain terhadapnya. Dia berperilaku sesuai dengan yang diharapkan ketika berada di kantor dan ketika berinteraksi di rumah dengan keluarganya dia juga harus berperilaku sesuai dengan yang diharapkan juga.

\section{Metode Penelitian}

Jenis penelitian yang digunakan dalam penelitian ini adalah analitik dengan desain cross sectional dengan tujuan untuk melihat hubungan role family conflict dan stres kerja pada perawat wanita di Rumah Sakit Putri Hijau Medan. 
Lokasi yang digunakan dalam penelitian ini adalah seluruh ruangan yang berada di Rumah Sakit Putri Hijau Medan.

Penelitian ini dilakukan mulai bulan Februari sampai Mei 2016. Sampel dalam penelitian ini adalah perawat wanita yang bertugas di Rumah Sakit Putri Hijau sebanyak 76 orang.

\section{Pembahasan}

Hasil utama penelitian ini meemperlihatkan bahwa ada hubungan positif antara konflik peran ganda dengan stres kerja pada wanita bekerja, dimana semakin tinggi konflik peran maka semakin tinggi pula stres kerjanya. Dimana tingkat korelasi antara kedua variabel ini adalah 0.777 .

Hasil penelitian ini sesuai dengan hipotesa awal yang mengatakan bahwa ada hubungan yang positif antara konflik peran ganda dengan stres kerja pada wanita bekerja.

Hasil penelitian ini sesuai dengan apa yang dikemukakan oleh Settless, dkk (2002) yang menyebutkan bahwa peran ganda yang dijalankan wanita, baik sebagai ibu rumah tangga maupun sebagai wanita yang bekerja, dapat menimbulkan konflik peran. Konflik yang berkepanjangan dapat menyebabkan timbulnya respon fisiologis, psikologis dan tingkah laku sebagai bentuk penyesuaian diri terhadap kondisi yang mengancam yang disebut dengan stres.

Sejalan dengan itu, pelaksanaan peran ganda wanita pada kenyataannya memang menimbulkan masalah yang tidak sedikit (Soeharto, 2004). Peran ganda memungkinkan terjadinya konflik peran dimana suatu perilaku yang diharapkan pada suatu posisi tidak cocok dengan posisi yang lain (Oskamp, 1984). Simon (2002) juga menyatakan wanita bekerja mendapatkan sejumlah implikasi klinis dan efek psikologis ketika bernegosiasi dengan konflik internal dan eksternalnya. Pengalaman konflik wanita bekerja sering menimbulkan depresi, perasaan stres, rasa bersalah, cemburu dan malu (Hammen dalam Simon, 2002).

Berdasarkan uji normalitas dengan menggunakan Kolmogorov-Smirnov test, pada penelitian ini diperoleh hasil variabel stres kerja menunjukkan sebaran normal dengan nilai $\mathrm{Z}=1.064$ dan $\mathrm{p}=0.208$, sedangkan hasil variabel konflik peran ganda juga menunjukkan sebaran normal dengan nilai $\mathrm{Z}=0.705$ dan $\mathrm{p}=0.703$.

Uji linearitas pada penelitian ini menggunakan compare means test for linearity dan diperoleh nilai $\mathrm{F}=141.900$ dengan signifikansi (p) sebesar 0.000, sehingga dapat disimpulkan bahwa hubungan kedua variabel tersebut linear karena nilai signifikansi $\mathrm{p}<0.05$.

Berdasarkan hasil uji hipotesa dengan menggunakan Analisa Regresi Linear Sederhana, pada penelitian ini diperoleh nilai signifikansi (p) sebesar 0.000, sehingga dapat dikatakan bahwa variabel bebas berpengaruh terhadap variabel tergantung. Dengan demikian, hipotesa pada penelitian ini diterima yakni terdapat hubungan antara konflik peran ganda dengan stres kerja.

Kontribusi variabel konstanta (stres kerja) degan variabel predictor (konflik peran ganda) pada penelitian ini menunjukkan koefisien ( $\mathrm{R}$ square) sebesar 0.604, hal ini mengindikasikan bahwa sebesar $60.4 \%$ dari seluruh seluruh variabel total stres kerja dapat diterangkan dari model yang sisanya $39.6 \%$ diterangkan faktor-faktor lain yang tidak diperhitungkan ke dalam model.

Pada penelitian ini, koefisien regresi konflik peran ganda diperoleh dari Unstadardized Coefficients dengan model regresi y = $41.705+0.527 \mathrm{x}$ dengan $\mathrm{x}$ adalah konflik peran ganda dan y adalah stres kerja. Ternyata dari tingkat kepercayaan $95 \%$ untuk setiap pertambahan konflik peran ganda naik sebesar 1 skor, stres kerja naik antara 0.429 dan 0.626 .

Berdasarkan 76 wanita bekerja pada penelitian ini, didapat bahwa mayoritas wanita bekerja memiliki tingkat stres kerja yang berada pada taraf sedang sebanyak 67 orang $(88.2 \%)$, yang berarti ketidakmampuan untuk memahami atau menghadapi tekanan terhadap perubahan lingkungan atau keadaan dinilai sedang. Selain itu, mayoritas wanita bekerja memiliki tingkat konflik peran ganda yang berada pada taraf sedang sebanyak 68 orang $(89.5 \%)$. ketidakcocokan antara harapan yang berkaitan dengan suatu peran yang dialami wanita bekerja dinilai sedang.

Hasil lain yang diperoleh dalam penelitian ini, yakni para wanita bekerja memiliki konflik peran ganda yang tergolong rendah. Hal ini diketahui dari nilai mean empirik konflik peran ganda 127.18 yang lebih kecil dari nilai mean hipotetik 135. Demikian pula halnya dengan stres kerja yang rendah, karena nilai mean empirik 198.79 yang lebih kecil daripada nilai mean hipotetik 125 .

Dalam penelitian ini juga terdapat beberapa kekurangan, seperti dalam penentuan populasi dan sampel penelitian, dimana sebaiknya data diambil dari suatu perusahaan yang memiliki banyak karyawan wanita yang sudah menikah. Penelitian ini hanya menggunakan nonrandom samping yakni incidental sampling, dimana hanya individu-individu yang kebetulan dijumpai atau dapat dijumpai saja yang diselidi (Hadi, 2000).

\section{Simpulan}

Berdasarkan hasil analisa dan interpretasi data penelitian dapat ditarik kesimpulan mengenai hasil penelitian, bahwa :

1. Ada hubungan positif antara konflik peran ganda dengan stres kerja pada wanita bekerja, artinya semakin tinggi konflik peran ganda semakin tinggi pula stres kerja pada wanita, dan 
sebaliknya semakin rendah konflik peran ganda semakin rendah pula stres kerja pada wanita bekerja.

2. Berdasarkan penelitian ini, mayoritas wanita bekerja memiliki tingkat stres kerja pada taraf sedang yang berarti ketidakmampuan untuk memahami atau menghadapi tekanan terhadap perubahan lingkungan atau keadaan dinilai sedang.

3. Berdasarkan penelitian ini, mayoritas wanita bekerja memiliki tingkat konflik peran ganda pada taraf sedang yang berarti ketidakcocokan antara harapan yang berkaitan dengan suatu peran yang dialami wanita bekerja dinilai sedang.

4. Berdasarkan hasil analisa tambahan diperoleh bahwa tidak ada perbedaan konflik peran ganda ditinjau dari usia, pendidikan terakhir, pekerjaan, masa kerja, jumlah anak, dan usia anak terkecil.

\section{Saran}

Dari penelitian yang telah dilakukan dan kesimpulan yang dikemukakan, maka peneliti mengemukakan beberapa saran antara lain:

1. Bagi peneliti yang tertarik melakukan penelitian mengenai konflik peran ganda dan stres kerja yang selanjutnya sebaiknya meneliti aspek yang lebih mendalam seperti faktor keluarga dan pola asuh orang tua.

2. Untuk lebih memperkaya penelitian dengan tema serupa sebaiknya penelitian yang selanjutnya meneliti faktor-faktor lain yang mungkin mempengaruhi seperti time pressure; family size dan support; kepuasan kerja; dan marital and life satisfaction.

3. Penelitian selanjutnya dipandang perlu untuk memperhatikan proporsi jumlah subjek penelitian baik dalam usia, pekerjaan, dan jumlah pegawai di tempat kerja.

\section{Daftar Pustaka}

Ancok, J,. dan Suroso, F. (2005). Psikologi Islami: Solusi Islam atas Problem-Problem Psikologi. Yogyakarta: Pustaka Pelajar.

As'ad, M. (1990). Psikologi Industri. Edisi Keempat. Yogyakarta: Liberty.

Austin, M.W. (2004). Occupational Stress and Coping Mechanisms as perceived by the Directors of Adult Literacy Educational Programs in Texas. Journal of

Dessler, G. (1997). Human Resource Management 7th edition, New Jersey: Prenctice Hall.

Dharmawan, L.L, (2005). Prinsip-prinsip Dukungan Psikososial Pascabencana. Jurnal Psikologi. Tanggal akses 05 April 2008
Diahsari, E.Y. (2001). Kontribusi Stres pada Produktivitas Kerja. Surabaya : Anima : Indonesian Psychologycal Journal.

Effendi, M. (2001). Stres Akibat Kerja yang Dihadapi Oleh Guru Sekolah Luar Biasa. Jurnal Umum Psikologi. Tanggal akses 19 Maret 2009.

Egelman, W. (2004). Understanding Families. New York: Pearson Education.

Greenhause, J.H. dan Beutell, N.J. (1985). Sources of conflict between work and family roles. Academy of Management Review, 10 (1), 76-88.

Gunarsa, S, dan Gunarsa, D. (2000). Psikologi praktis: Anak, remaja dan keluarga. Jakarta: Gunung Mulia

Gunn, J.B. (1994). Women in Midlife. Plenum Press : New York and London.

Hadi, S. (2000). Metodologi Research (jilid 1). Yogyakarta : Andi Offset.

Handoko, T.H. (1995). Managemen Personalia. Yogyakarta : Yayasan Penerbitan Fakultas Ekonomi UGM.

Hardyastuti, S. (2001). Pengurangan Konflik Peran Kerja dan Peran Keluarga : Siapa Pelakunya?. Jurnal Psikologi. Tanggal Akses : 12 Januari 2009.

Hennessy, T. (2005). Work-family conflict selfefficacy: A scale validation study. Journal of Manageril Psychology. Tanggal akses: 17 Mei 2009.

Hurlock, E.B. (1999). Psikologi perkembangan: Suatu pendekatan sepanjang rentang kehidupan (Edisi ke-5). Jakarta: Penerbit Erlangga.

Ihromi, T.O. (1990). Para Ibu yang Berperan Tunggal dan yang Berperan Ganda. Jakarta : Lembaga Penerbit FE-UI.

Wiley, C. (2000). A Synthesis of Research on the Causes, Effects, and Reduction Strategies of Teacher Stress. Journal of Instructional Psychology.

Wolfman, B.R. (1994). Peran Kaum Wanita: Bagaimana Menjadi Cakap dan Seimbang dalam Aneka Peran. Yogyakarga : Penerbit Kanisius.

Yulia, A. (2007). Working Mom \& Kids. PT. Elex Media Komputindo : Jakarta. 